\title{
原子力の安全規制の最適化に関する研究会の活動* (格納容器漏えい率試験)
}

野間格*1

\section{Research Section on Optimization of Nuclear Safety Regulation (Containment Leakage Rate Testing)}

\author{
Tadashi NOMA*2 \\ *2 Kyushu Electric Power Company \\ 2-1-82 Watanabe-dori, Chuo-ku, Fukuoka-shi, Fukuoka, 810-8720 Japan
}

As a part of the study group's work on Optimization of Nuclear Safety Regulation of JSME, we studied the current experience and information about Containment Leakage Rate Testing (CVLRT) in the U.S. and European countries. After that, we compared their methods with the methods of CVLRT used in Japan. The results of our studies were summarized as follows: 1) In the U.S., NRC de-regulated the CVLRT methods so that the utilities could select the most efficient and the safest method. 2) In France and Belgium, the OLM (Online Leakage Monitoring) is used.

Key Words: Nuclear Power Generation, Engineering Optimization, Containment Leakage Rate Testing (CVLRT), Nuclear Safety Regulation

\section{1.はじめに}

現在検討されている新検査制度では，プラント毎の 特性に応じて原子炉停止間隔を設定することが可能と なる。このため，既に長期サイクル運転を導入してい る米国等について，国内では，現状 13 か月毎の定期検 查で実施している試験の1つである格納容器漏えい率 試験の制度，頻度を調查し，我が国との比較検討を行 った.

\section{2. 米国における格納容器漏えい率試験}

\section{$2 \cdot 1 \quad$ 米国における格納容器漏えい率試験要件の法} 令体系米国 NRCの規制では，格納容器漏えい率 試験要件は連邦規則 10 CFR 50 の附則 J (軽水型発電 炉に対する原子炉格納容器漏えい率試験) にて規定さ れており，この附則の遵守が 10 CFR 50 の本文 $[10$ CFR 50.54(0)] で認可条件の一つとして要求されて いる，附則 Jでは，格納容器漏えい率試験に関する具 体的な要件が示されているが，この要件を満たす方式

* 原稿受付 2008 年 9 月 22 日.

*1 正員, 九州電力 (株) (雪 810-8720 福岡市中央区渡辺通 2-1 $82)$.

E-mail : Tadashi_Noma@kyuden.co.jp
としては，オプション $\mathrm{A}$ とオプション $\mathrm{B}$ が併記され ており，事業者はいずれかの方式に従光ば良いとされ ている.

オプションAは，この附則が定められた1973年か ら規定されていた方式であり，全体瀮えい率試験を 10 年に 3 回実施することを基本とし，漏えい率の As Found の值が不合格の場合に，試験間隔を短縮するこ とが求められている。

一方，オプション B は，パフォーマンスに基づく規 制であり，1995年に追加されたものである。このオプ ションの場合, 全体漏えい率試験の間隔は過去のパフ オーマンスに基づいて定期的に実施することが求めら れているが，試験間隔の具体的な設定方法は特に規定 されていない.オプション Bを採用した場合の試験 間隔については，10 年以内に 1 回実施することを基本 とする指針(NEI-94-01)が民間機関である NEIから 出されており,この指針が Reg. Guide 1.163により 承認されている。

なお，試験間隔以外の試験要件（試験圧力，静定時間 等)については，米国国家規格 ANSI/ANS-56.81994 が Reg. Guide 1.163 により承認されている.

$2 \cdot 2$ リスク評価に基づく試験間隔の更なる延長

NRCは1984 年の戦略計画書において,「不必要な規 


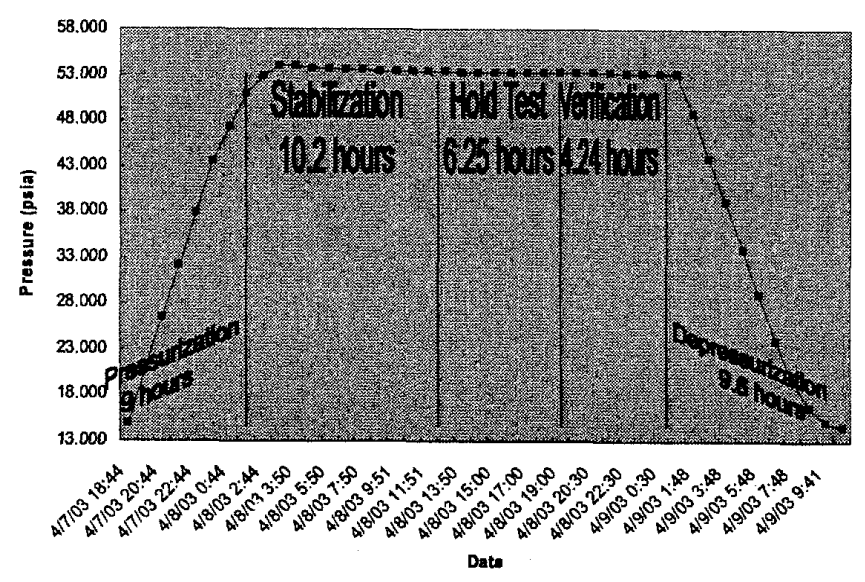

Fig. 1 Pressure curve of CVLRT

制上の負荷を廃止し，NRC の安全上の目的を満足さ せる最もコスト効果的な方策を事業者が柔軟に選択出 来るょうにする.」との方針を提示し，元の一還とし て格納容器全体漏えい率試験の規制条件の緩和が検討 された。この検討の中で格納容器全体漏えい率試験要 件を緩和した場合のリスクの変化が検討され，格納容 器の漏えいのほとんどは部分漏えい試験 $(\mathrm{B}, \mathrm{C}$ 種試 験)により検知されるため, 全体漏えい率試験 (A 種試 験)間隔を 20 年に延長しても一般的なプラントでのリ スクの増加は僅かであるとの結論が得られた (NUREG-1493)，前述のオプションBの採用はこの 検討結果を踏まえたものであるが，この検討成果に基 づき，自己の発電所に対するリスク評伍結果に基づき 試験間隔を 10 年以上にすることの特例申請が出され 承認されており，米国では，延長期間を15 年にしてい る発電所が多い。な扔，この様な申請は，過去の A 種 試験が良好であること, 次回の 10 年に 1 回毎の試験 を，申請されている時期まで延期しても公衆の受ける リスクの増加は僅かであること，評価に用いたPSA の品質は充分に良好であること，の条件が満足されて いる場合に承認されている。

$2 \cdot 3$ 米国の発電所の現状 米国の 2 箇所の原子 力発電所以扔ける格納容器全体漏えい率試験の調查を 行った。両発電所とも, 前述の $10 \mathrm{CFR} 50$ の附則 J の オプション Bの規定に従って実施している.オプシ ヨンBでは 10 年に 1 回の試験が許されているため, 24 か月運転サイクルへの移行に際しての問題とはな っていない.

図 1 に米国の A 原子力発電所に㧈りる格納容器全 体漏えい率試験の圧力昇降圧曲線について示吉。図 1 より，格納容器全体漏えい率試験は，ほほ日本と同様 の「加圧」「安定」「ホールドテスト」「確認」「減圧」 の5つのプロセスで行われていることが分かる.

\section{3. 欧州における格納容器漏えい率試験要件概要}

前述の格納容器全体漏えい率試験の規制条件の緩和 に関する NRCの報告書(NUREG-1493)では，全体漏 えい率試験の代替案として，フランス，ベルギー及び カナダに拈けオンラインの漏えい監視システム (OLM)が紹介されている.

$3 ・ 1$ フランス フランスでは, 運開後最初の燃 料交換停止時に格納容器全体漏えい率試験を実施し, その後は 10 年每に実施する事が求められている(試験 結果が良好な場合)。試験压力は LOCA 時のピーク圧 力である。この漏えい試験を補完するものとして， OLM 1985 年からすべての PWR に導入している. この OLM は, 計測用ラインから格納容器内に意図的 に空気を流入させて加圧し，内圧の変化から漏えい量 を推定するものである. 加圧速度は，100 mbar \{1.5 $\mathrm{psi}\} / 20$ 日であり，生力が予め設定された上限值に達 すると, 格納容器圧力は手動で速やかに減圧された後, 再度加圧が開始される。温度は 10 か所, 湿度は 2 か 所, 圧力 2 か所(格納容器内圧と外圧)で測定される. 漏えい率測定結果に基づく対応が定められており，大 きな漏えい量が検知され一定期間内に漏えい箇所が隔 離出来ない場合には，原子炬が停止される。

このシステムは, 疑わしい漏えい箇所を隔離して漏 えい率の変化をみることにより，漏えい箇所検知にも 利用されており，1980年に初めて設置した際に，放射 線モニタリング系とサービス空気系の漏えいを検知・ 隔離している.

$3 \cdot 2$ ベルギー ベルギーでは, 格納容器全体漏 えい率試験は, 10 年に 1 回, LOCA 時ピーク圧力の半 分以上の圧力で実施することが求められている。 た, 事業者は, 格納容器漏えいのオンラインモニタリ ングシステムを運用している。

このシステムは, 珠縮空気系から格納容器内への (意図的ではない)漏えい量と格納容器の圧力, 温度, 湿度 (温度は 30 箇所, 湿度は 5 10 箇所)を測定する ことにより, 格納容器漏えい率を求めるものである。 通常，この漏えいによる王力上昇は $0.5 \sim 1 \mathrm{mbar} / \mathrm{h}$ であり，一方，合理的な精度で漏えい率を推定するた めには，少なくとも 0 〜 $50 \mathrm{mbar}$ 程度の圧力変化が必 要とされている(測定間隔 30 秒で 15 分平均值を使 用)。このため，一回の測定には少なくとも50 時間程 度は必要とされ，かつその間に格納容器圧力に大きな じょう乱が発生しないことが前提となっている.

$3 \cdot 3$ 米国 NRCの見解 これらの OLM 方式を 紹介している米国 NRCの報告畫(NUREG-1493)で 
は, これらのOLM は, 格納容器全体漏えい率試験 $(\mathrm{A}$ 種試験)よりは測定精度は落ちるが, 大きな漏えいを 迅速に检知する方法としては有効であろうとしつつ, 格納容器の漏えい障壁性が要求される事故時俚力下で の格納容器健全性と気密性を確認するものではないた め, A 種試験に置き換えることは出来ないと結論づけ ている.

\section{4. 国内 調 查}

$4 \cdot 1$ 沸騰水型原子炉（BWR） BWRに抢いて は, 「原子炉格納容器の漏之い率試験規程 (JEAC 4203-2004）」に従い, 定期検査每に全体漏えい率試験 ( $\mathrm{A}$ 種試験)を設計区力にて実施している。このA 種 試験の継続試験時間については, JEAC 4203-2004に おける但し書きに従い, 通常の定期検查に扔いては測 定時間を 6 時間, 10 年に 1 回の定期検查に抒いては 24 時間で実施している.
$4 \cdot 2$ 加圧水型原子炉 $(\mathrm{PWR}) \quad \mathrm{PWR}$ にいて は, 「原子炻格納容器の漏えい率試験規程 (JEAC 4203-2004)」に從い, 全体漏えい率試験 (A 種試験) と 局部漏光い率試験 ( $\mathrm{B}, \mathrm{C}$ 種)の組み合わせにて実施し ている $(\mathrm{A}$ 種と $\mathrm{B}, \mathrm{C}$ 種の相関が認められた場合)。こ の $\mathrm{A}$ 種試験 (3 回に 1 回) は, 設計圧力試験の压力で実 施しなければならないと規定されているが, PWRに おいては，JEAC 4203-2004に打ける低圧試験の許容 漏えい率に従えば，低圧試験の圧力で実施してもよい となっている。 また，改定 JEAC 4203-2008では, 10 年に一度は設計圧力による $\mathrm{A}$ 種試験を実施すること となる。

\section{5. まと め}

米国の格納容器漏えい率試験は, 我が国のそれに比 べて，試験頻度において事業者の選択の幅が大きく， 柔軟に対応が可能であることが分かった。 